\title{
FIRST PUBLISHED RECORDS OF CATOPTRIA ACUTANGULELLUS (HERRICH-SCHÄFFER, 1847) (LEPIDOPTERA:CRAMBIDAE) IN CROATIA AFTER ALMOST A CENTURY
}

\section{Danijela Gumhalter ${ }^{1} \&$ Mladen Kučinić $^{2}$}

${ }^{1}$ Azuritweg 2, 70619 Stuttgart, Germany (e-mail: danijela.gumhalter@gmail.com) ${ }^{2}$ Department of Biology, Faculty of Science, University of Zagreb, Rooseveltov trg 6, 10000 Zagreb, Croatia (e-mail: kucinic@biol.pmf.hr)

Gumhalter, D. \& Kučinić, M.: First published records of Catoptria acutangulellus (HerrichSchäffer, 1847) (Lepidoptera: Crambidae) in Croatia after almost a century. Nat. Croat., Vol. 29, No. 1, 129-134, Zagreb, 2020.

The montane species Catoptria acutangulellus (Herrich-Schäffer, 1847) was reconfirmed from Croatia on Mt Biokovo after almost 100 years. Previous historical records were published in 1850 from Mt Biokovo and 1896 from the area around Rijeka. There are no recently published records of this species, whether from Mt Biokovo or any other Croatian mountain. Therefore, these new records also represent the first findings of this species for Mt Biokovo in more than 140 years. Habitat loss or habitat change due to global warming could be a threat to montane species such as C. acutangulellus. Since the only known localities of C. acutangulellus in Croatia are the highest parts of Mt Biokovo, in the future it could be a threatened species in the country.

Altogether 15 specimens of $C$. acutangulellus were collected during a field trip to Mt Biokovo, on $20^{\text {th }}$ August 2019. Later on, another 15 specimens were discovered from the same area in the Kučinić Collection from CNHM in Zagreb. All specimens were collected by the second author in the 1990s. These findings reconfirm the presence of $C$. acutangulellus in the fauna of Croatia and provide evidence that this species is still present on Mt Biokovo.

Keywords: Catoptria acutangulellus, Pyraloidea, Biokovo, Croatia, fauna, collections, CNHM

Gumhalter, D. \& Kučinić, M.: Prvi objavljeni nalazi vrste Catoptria acutangulellus (HerrichSchäffer, 1847) (Lepidoptera: Crambidae) za Hrvatsku nakon gotovo jednog stoljeća. Nat. Croat., Vol. 29, No. 1, 129-134, Zagreb, 2020.

Nakon skoro 100 godina na planini Biokovu je za Hrvatsku potvrđena planinska vrsta Catoptria acutangulellus (Herrich-Schäffer, 1847). Prethodni nalazi potječu iz 1850. s Biokova i iz 1896. godine iz okolice Rijeke. Ne postoje recentni objavljeni nalazi za ovu vrstu, niti s Biokova, niti nekog drugog područja Hrvatske. Osim toga ovi novi nalazi predstavljaju prve nalaze za područje planine Biokovo nakon više od 140 godina. Nestanak staništa ili promjene na staništima nastale uslijed globalnog zatopljenja mogli bi biti prijetnja planinskim vrstama kao što je $C$. acutangulellus. $S$ obzirom na to da su jedina poznata nalazišta ove vrste najviši dijelovi Biokova, u budućnosti bi ova vrsta mogla biti ugrožena u Hrvatskoj.

Tijekom terenskog istraživanja 20. kolovoza 2019. godine na Biokovu je ulovljeno ukupno 15 primjeraka vrste $C$. acutangulellus. U nastavku rada je također otkriveno 15 primjeraka s istog područja pohranjenih u Zbirci Kučinić u HPM-u u Zagrebu, prikupljenih 90-tih godina 20. st. Ovi dodatni nalazi potvrđuju prisustvo vrste $C$. acutangulellus u fauni Hrvatske te ukazuju na to da je ta vrsta i dalje prisutna na području planine Biokovo.

Ključne riječi: Catoptria acutangulellus, Pyraloidea, Biokovo, Hrvatska, fauna, zbirke, HPM 


\section{INTRODUCTION}

Although the study of Lepidoptera in Croatia goes back more than 200 years, the level of exploration varies, as research was predominately conducted in coastal parts of Croatia and rarely included continental and mountainous areas (Durbešıć, 2012). And when they were carried out, they rarely included microlepidopterous families, so few documents covering pyraloid moths are available. Therefore, little is known of the occurrence of Pyraloidea species from Croatian mountains.

A checklist of Pyraloidea species in Croatia was presented by Gumhalter (2019a, $2019 b)$. For the creation of this checklist, all available published historical and recent literature sources on this micromoth superfamily were considered. This detailed faunistic analysis of Pyraloidea fauna in Croatia also included an examination of some available museum collections and results from own field investigations.

During a moth survey in Biokovo Nature Park, the species Catoptria acutangulellus (Herrich-Schäffer, 1847) from the family Crambidae was reconfirmed for Croatia after more than a century. Altogether 15 specimens were collected on $20^{\text {th }}$ August 2019 close to Sveti Jure at approximately 1,600 meters above sea level $\left(43^{\circ} 20^{\prime} 21.0^{\prime \prime} \mathrm{N} 17^{\circ} 3^{\prime} 14.3^{\prime \prime} \mathrm{E}\right)$. Another 15 specimens were discovered while the Kučinić Collection of the Croatian Natural History Museum in Zagreb was being examined later the same year. The discovered specimens from the Kučinić Collection were all collected in the 1990s, at five different localities and at altitudes above 1,270 meters above sea level: Vošac $\left(43^{\circ} 18^{\prime} 47.32^{\prime \prime} \mathrm{N} 17^{\circ} 3^{\prime} 7.8^{\prime \prime} \mathrm{E}\right)$, Sveti Jure (4320 $\left.31.9^{\prime \prime} \mathrm{N} 17^{\circ} 3^{\prime} 11.7^{\prime \prime} \mathrm{E}\right)$, Trajna ploha, Lađena $\left(43^{\circ} 17^{\prime} 58.6^{\prime \prime} \mathrm{N} 17^{\circ} 4^{\prime} 24.2^{\prime \prime} \mathrm{E}\right)$ and close to Sveti Jure $\left(43^{\circ} 20^{\prime} 21.0^{\prime \prime} \mathrm{N} 17^{\circ} 3^{\prime} 14.3^{\prime \prime} \mathrm{E}\right)$.

The only records of $C$. acutangulellus in Croatia originate from historical literature sources. Since its first collection on Mt Biokovo in 1850 (MANn, 1869) it has been recorded only once more in Croatia, in 1896 in the area around Rijeka (ABAFI-Aigner et al., 1896). Therefore, our recent findings provide evidence that C. acutangulellus is still present in the fauna of Croatia, as well as on Mt Biokovo.

Due to the lack of published records, the current status of C. acutangulellus in Croatia is unclear. It is possible that this montane species inhabits other Croatian mountains, as well. Nonetheless, the only known localities in Croatia are the highest parts of $\mathrm{Mt}$ Biokovo. It can be expected that in the future rising temperatures in the mountains will force montane species such as C. acutangulellus uphill. Global warming can cause habitat changes or habitat loss and therefore may have a negative impact on biodiversity. Our study aims to contribute to the knowledge of Pyraloidea species occurring in Croatian mountains and to review published records on C. acutangulellus in Croatia. These findings represent the first records of C. acutangulellus in Croatia in almost 100 years and in more than 140 years for Mt Biokovo.

\section{MATERIALS AND METHODS}

The first author conducted field investigations on Mt Biokovo. Amongst the collected material there were several specimens of C. acutangulellus (Fig. 1), which all originate from the same locality close to the peak Sveti Jure. All specimens were collected in a dry and open, limestone rocky habitat (Fig. 2). All specimens were caught with a UV light trap and are deposited in the private collection of the first author (coll. Gumhalter). The determination was conducted according to SLAMKA (2008). 


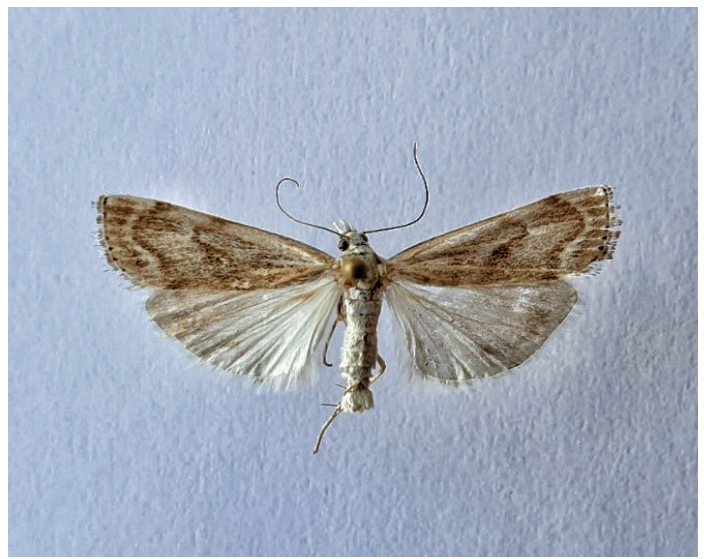

Fig. 1. One specimen of C. acutangulellus collected on $20^{\text {th }}$ August 2019 at approximately 1,600 meters above sea level (photo: D. Gumhalter)

The second author conducted several field trips between 1985 and 2018 and collected about 600 specimens of pyraloid moths in different localities in south Croatia, including Biokovo Nature Park. All moths were caught with a UV light trap and the specimens collected were deposited in his collection within the Croatian Natural History Museum in Zagreb (coll. Lepidoptera Kučinić). The results of his research from Mt Biokovo were never published.

While examining the specimens deposited in the Kučinić Collection we also discovered several specimens of the species $C$. acutangulellus. The determination of species was also conducted according to SLAMKA (2008), but to assure identification, genitalia slides were made as well. The analysis of the morphological characteristics of the genitals was done according to SlAmKa (2008).

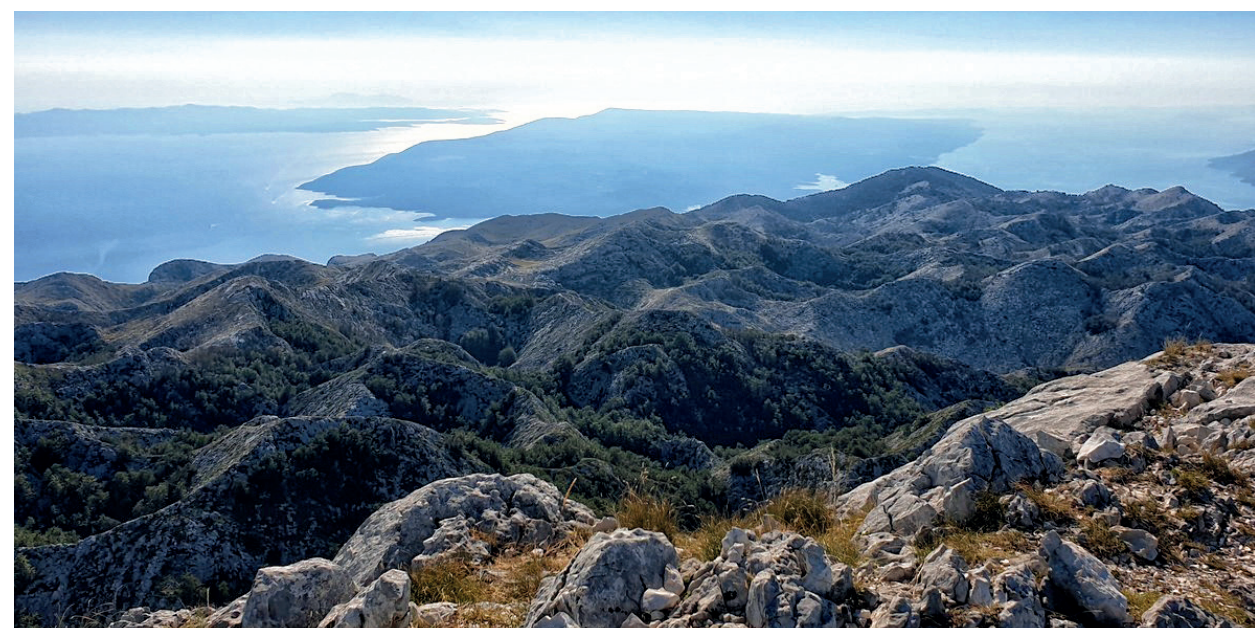

Fig. 2. A dry, open, rocky, limestone habitat on the highest parts of Mt Biokovo, the location where $C$. acutangulellus was collected in 2019 (photo: D. Gumhalter) 


\section{RESULTS AND DISCUSSION}

According to van NieUKERKEn et al. (2011), there are 9,655 described species within the family Crambidae. There are 207 species from the family Crambidae and 14 species from the genus Catoptria Hübner, 1825 currently recorded for Croatia (Gumhalter, 2019).

The montane moth C. acutangulellus was first described by HerRich-ScHÄFFER (1847). It inhabits rocky or limestone habitats that are dry and open, usually between the altitudes of 1,300 and 2,100 meters above sea level. The species is very variable in the colouration and intensity of forewing markings (SLAMKA, 2008). The ground colour of its forewings is usually white with distinct markings (cross lines), but a greyish ground colour is also possible. SLAmKa (2008) states that the species is distributed in the southeastern Alps, Dalmatia, Bosnia and Hercegovina, Republic of North Macedonia, Albania, Greece, Bulgaria and maybe Sicily. Data from the Pyrenees and the Alps in France are not confirmed.

Another similar montane species of the genus Catoptria is present in Europe. Like C. acutanguellus, the species C. olympica (Ganev, 1983) also inhabits rocky limestone habitats in the mountains. But Slamka (2008) states that this species is distributed only in Greece on Mt Olympus and in Bulgaria on Mt. Belasitsa, above an altitude of 1,700 up to 2,500 metres above sea level. According to relevant literature of the Balkan region (SLAmKA, 2008; Plant \& JaKšıć, 2018, Gumhalter, 2019), no other localities of this species are known.

For the correct identification of the species genitalia slides were made. Analysis of these slides showed that the specimens caught undoubtedly belong to C. acutanguellus.

During the field investigation conducted on Mt Biokovo, 15 specimens of the montane species C. acutangulellus were collected. Later on the same year, another 15 specimens were discovered during an examination of the Kučinić Collection.

All specimens were collected on $20^{\text {th }}$ August 2019 on the highest parts of the mountain, on a locality at approximately 1,600 meters above sea level in a dry, rocky habitat close to the peak Sveti Jure (1,762 meters above sea level). The specimens from the Kučinić Collection were also collected at altitudes higher than 1,270 meters above sea level. Six out of these 15 specimens were collected on $25^{\text {th }}$ July 1992 at Vošac $(1,421$ m.a.s.1.), one on $26^{\text {th }}$ July 1992 at Sveti Jure (1,762 m.a.s.l.), one on $23^{\text {rd }}$ July 1994 at Trajna ploha (1,450 m.a.s.1.), two on $24^{\text {th }}$ July 1994 at Lađena (1,270 m.a.s.1.) and five on $26^{\text {th }}$ July 1995 close to Sveti Jure (1,594 m.a.s.1.). The position of Mt Biokovo in Croatia and an overview of all records of $C$. acutangulellus in Croatia are shown in Figure 3.

Consultation with relevant literature revealed that it has not been recorded in Croatia since 1896 and on Mt Biokovo since 1850. Afterwards, no additional records were published. Although C. acutangulellus was mentioned in several historical literature sources (Wocke, 1871; Rebel, 1904; Plant \& JAKšIĆ, 2018), none of the authors reported new findings but cited only the records from Mann (1850) and AbAfi-Aigner et al. (1896).

The recent discovery confirms that $C$. acutangulellus is still present in the fauna of Croatia and that it is presumably a permanent resident on Mt Biokovo.

Climate change and habitat loss may have a negative impact on biodiversity. Since the only recent known localities of $C$. acutangulellus in Croatia is the highest parts of Mt Biokovo, it could be a threatened species in Croatia. Although these recent findings indicate that it is a permanent resident on Mt Biokovo, habitat change due to global warming could be a threat to montane species such as $C$. acutangulellus in the future. 


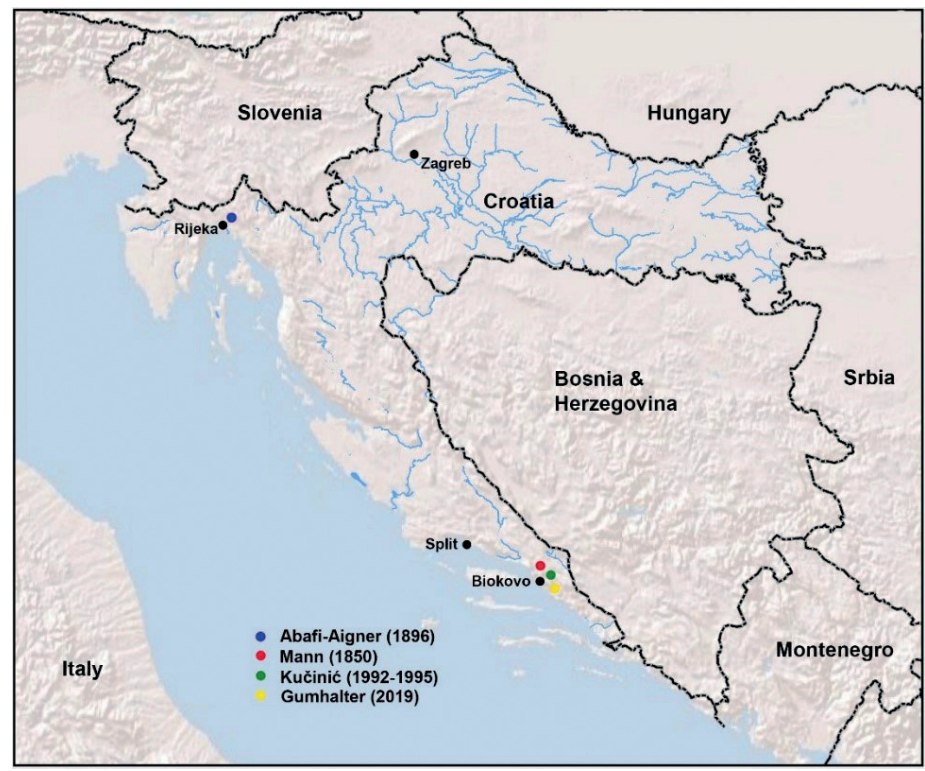

Fig. 3. Map with the position of Mt Biokovo and all known records of C. acutangulellus in Croatia.

Climate change over the past three decades has produced numerous shifts in the distributions and abundances of species (PARmesan \& Yohe, 2003; Root et al., 2003). It can be expected that rising temperatures in the mountains will force butterflies and moths uphill, colonizing areas with higher altitudes and latitudes (HickLING et al., 2006). However, reactions to climate change can significantly differ depending on their habitat location (e.g. altitude), feeding regime (e.g. polyphagous or monophagous) and host plant (good or inferior quality) (Kocsis \& HufnAgeL, 2011). Therefore, further studies should focus on C. acutangulellus as a montane moth. Investigations should be aimed at its potential distribution in other Croatian mountains, as well as at its feeding and habitat preferences on Mt Biokovo. It is unclear, if $C$. acutangulellus is widespread on Mt Biokovo or only locally present in some habitats. Future studies should also include the further sampling of Pyraloidea species in Biokovo Nature Park to contribute to the knowledge of the overall pyraloid moth fauna of this particular mountain.

Received March 3, 2020

\section{REFERENCES}

Abafi-Aigner, L., Pavel, J. \& Uhryk, F., 1896: Fauna Regni Hungariae. Lepidoptera. Regia Societas Scientiarum Naturalium Hungarica, Budapest, 82 pp.

DurbešIĆ, P., 2012: Hrvatska Entomofauna iz sadašnjosti pogled unatrag i planovi za budućnost. Entomologia Croatica 16 (1), 5-88.

Gumhalter, D., 2019a: First checklist of pyraloid moths (Lepidoptera: Pyraloidea) in Croatia. Zootaxa 4604 (1), 059-102. https://doi.org/10.11646/zootaxa.4604.1.3

Gumhalter, D., 2019b: A revised checklist of pyraloid moths (Lepidoptera: Pyraloidea) in Croatia. Nature Croatica 28 (2), 271-288.DOI: 10.20302/NC.2019.28.20 
Herrich-Schäffer, G.A.W., 1847-1855: Systematische Bearbeitung der Schmetterlinge von Europa, zugleich als Text, Revision und Supplement zu Jakob Hübner's Sammlung europäischer Schmetterlinge. Vierter Band. Die Zünsler und Wickler, Regensburg, p. 32.

Hickling, R., Roy, D.B., Hill, J.K., Fox, R., Thomas, C.D., 2006: The distributions of a wide range of taxonomic groups are expanding polewards. Global Change Biology 12, 450-455.

Kocsis, M. \& Hufnagel, L., 2011: Impacts of climate change on Lepidoptera species and communities. Applied Ecology and Environmental Research 9 (1), 43-72.

MANN, J., 1869: Lepidopteren gesammelt während dreier Reisen nach Dalmatien in den Jahren 1850, 1862 und 1868. Verhandlungen der kaiserlich-königlichen zoologisch-botanischen Gesellschaft 19, 371-388.

Nieukerken van, E. J., Kaila, L. \& Kitching, I. J., 2011: Order Lepidoptera. Animal biodiversity: An outline of higher-level classification and survey of taxonomic richness. Zootaxa 3148, 212-221.

Parmesan, C. \& Yohe, G. A., 2003: globally coherent fingerprint of climate change impacts across natural systems. Nature 421, 37-42. https://doi.org/10.1038/nature01286

Plant, C.W. \& JAKŠı́, P., 2018: A provisional checklist and bibliography of the Pyraloidea of the Balkan Peninsula (Lepidoptera: Pyralidae \& Crambidae). Atalanta 49, 219-263.

Rebel, H., 1904: Studien über die Lepidopterenfauna der Balkanländer. II. Teil. Bosnien und Herzegowina. Annalen des Naturhistorischen Museums in Wien 19, 97-377.

Root, T. L., Price, J. T., Hall, K. R., Schneider, S. H., Rosenzweig, C. \& Pounds, J. A., 2003: Fingerprints of global warming on wild animals and plants. Nature 421, 57-60. https://doi.org/10.1038/nature01333

Slamka, F., 2008: Pyraloidea of Europe (Lepidoptera) Volumen 2. Crambinae \& Schoenobiinae. Frantisek Slamka, Bratislava (Eigenverlag František Slamka).

Wocke, M. F., 1871: Microlepidoptera. In: Staudinger, O. \& Wocke, M.F. (Eds.), Catalog der Lepidopteren des Europaeischen Faunengebiets. Dr. O. Staudinger und Hermann Burdach, Dresden, pp. 1-426. 